\title{
6
}

\section{Reconciling sport and law}

The EU has been characterised as a regulatory state (Majone 1996). Embedded within the EU's constitutional and normative structure is a predisposition for the promulgation and enforcement of rules. In other words, the forces of negative as opposed to positive integration have historically driven the integration process (Pinder 1968, 1993). Knowledge about regulation and not budgets or votes has been the key resource EU officials have striven for. Yet knowledge has a 'dark side' - technocracy (Radaelli 1999b: 758 ) - and this essentially technocratic 'path' to integration has attracted criticism (see for instance Featherstone 1994). Although defended on the grounds of policy-making efficiency, technocratic integration raises important questions of transparency, accountability, legitimacy and democracy. As a consequence, in recent years evidence suggests that policy subsystems formerly dominated by technocratic and legal norms are becoming increasingly politicised (Radaelli 1999a, b). Radaelli for example has identified the single currency, tax policy and media ownership policy as three areas penetrated by political arguments (Radaelli 1999a).

As illustrated in Chapters 4 and 5, sport emerged on to the EU's systemic agenda through the ECJ rulings in Walrave, Donà and Bosman. It was then transferred to the institutional agenda through the quasi-legal venue of the Competition Policy Directorate. As such, the sports policy subsystem was initially dominated by legal Single Market regulatory norms as opposed to the essentially political socio-cultural arguments advanced by Adonnino (see Chapter 1 and below). The Adonnino sporting agenda stressed the social, educational and integrationist qualities of sport. For the EU to gain the more widespread support of its citizens, supporters of Adonnino stress the need for the EU's policy remit to reflect more socio-cultural concerns as opposed to narrow economic issues. The danger with the EU's market-based definition of sport adopted by the ECJ and Commission is that it threatens to undermine this agenda. This has contributed to the re-assertion of sociocultural ideas within the context of EU involvement in sport. As Rochefort and Cobb remind us, 'the uninterested [or in this case interested] become 
engaged in response to the way participants portray their struggle' (Rochefort and Cobb 1994: 5).

In order to achieve the full or partial re-definition of sport, the sociocultural coalition needs to politicise the regulatory environment within which sport operates. The successful politicisation of the sports policy subsystem is an essential pre-requisite for policy change. Without it, the subsystem will continue to be dominated by legal norms and the economic definition of sport will prevail. However, to achieve politicisation the sociocultural coalition require two conditions to be met.

First, they need to form a cohesive advocacy coalition in order to act as a counterweight to the dominant coalition. Evidence presented in Chapter 3 suggests that the socio-cultural coalition is a coalition of convenience and as such is not such a cohesive force. Within the coalition exist actors with differing visions of the future. For instance, members of the European Parliament's Culture Committee and Legal Affairs Committee are opposed to moves to re-impose sporting restrictions prohibited by Bosman whereas other actors such as sports bodies are keen to challenge the ruling. In addition, the Parliament wants to root sport within the Treaty as a way of underpinning EU action in the social and cultural aspects of sport, whereas the desire of sports organisations for sport to have Treaty status is a tactic to limit EU involvement in sport and thus safeguard the autonomy of sport.

The second requirement for the re-definition of sport is the ability to operate successfully in numerous institutional venues. As indicated in Chapter 3, this condition is broadly met. The Commission has the right of legislative and policy initiative, the Parliament has enhanced budgetary and legislative powers and the member states possess the ability to amend the Treaty and to agree politically persuasive soft law. The socio-cultural advocacy coalition therefore possesses considerable institutional resources in order to effect policy re-definition. The effective use of these resources is however problematic. Changes to primary legislation requires the unanimous support of the member states and changes to secondary legislation and budgetary lines requires considerable support within and between the EU institutions. Nevertheless, the lack of cohesion within the socio-cultural coalition and the absence of a Treaty base for sport represent significant obstacles to the fulfilment of the socio-cultural agenda.

This chapter examines the approach adopted by the socio-cultural coalition in six sections. The first examines the birth and development of sociocultural ideas between 1984 and 1995. The second section analyses the impact of Bosman on the nature, organisation and approach of the sociocultural coalition. Section three examines the first major breakthrough for the socio-cultural coalition - the annexing of a Declaration on Sport to the Treaty of Amsterdam in 1997. The fourth section analyses the impact of the Declaration and examines the birth of the 'new approach' to sports policy 
established throughout 1998 and 1999. The fifth section examines the 2000 Nice Declaration on Sport. Section six provides the concluding comment.

\section{The birth of socio-cultural ideas 1984-1995}

The birth of a socio-cultural sporting agenda can be traced to the 1984 Fontainebleau Summit. With economic and political integration stagnating and the legitimacy of the EU in the mind of the public faltering, the member states needed to 're-launch' European integration. In response, two committees were established to examine the possible avenues for this re-launch. The Dooge Committee reported on political reform and, although the measures were not directly acted upon, the Dooge proposals acted as the basis for discussion on Treaty reform at the 1985 intergovernmental conference. The Single European Act eventually emerged from these discussions.

The second committee (the Adonnino Committee) reported on measures that could strengthen the image of the EU in the minds of its citizens, thus addressing the legitimacy crisis. The creation of the Adonnino Committee marked the formal launch of an institutional commitment to the concept of a people's Europe and the first acknowledgement of the potential political uses of sport. The Adonnino Committee's report suggested a series of shortand long-term proposals that would contribute to the establishment of a people's Europe. ${ }^{1}$ The Committee identified eight categories of proposals, one of which concerned youth, education, exchanges and sport. The Committee's recommendations relating to sport are consistent with the general theme of the report. Interventionism and symbolism are evident throughout the Committee's recommendations. The main problem encountered by the Committee in relation to the 'use' of sport for the purposes of advancing the aim of a people's Europe, concerns the organisation of sport itself. The report recognised the autonomy of sporting organisations and was careful not to appear to challenge that autonomy. As a result, the Committee's sporting recommendations merely sought to encourage the sports sector to adopt measures, rather than requesting the European Council or Commission to act. The report's sports-related recommendations read:

Since ancient times sport has been an important forum for communication among people's. It is an important part of the lives of a large number of people within the Community. That is why it is all the more regrettable that the enjoyment of international competitive sport has been drastically marred recently by hooliganism. The Committee has therefore considered both of the these important aspects below.

5.9.1. The administration of sport is predominantly the responsibility of sports associations independent of government. The Committee proposes that the sports associations be invited to encourage action where it is consistent with their responsibilities, along these lines: 
i for certain sectors of sport, organisation of European Community events such as cycle and running races through European countries;

ii creation of Community teams for some sports to compete against joint teams from geographical groupings with which the Community has special links;

iii inviting sporting teams to wear the Community emblem in addition to their national colours at major sporting events of regional or worldwide interest; iv exchanges of sportsmen, athletes and trainers between the different Community countries, to be encouraged by programmes at the level of the Community and the member states;

$\mathrm{v}$ support for sporting activities especially for particular categories of persons, such as the handicapped. Student sport activities should be organised in conjunction with the twinning of schools and towns. ${ }^{2}$

The acceptance of the Adonnino Committee's recommendations marked more of a commitment to the concept of a people's Europe than it did to the development of a sports policy. Nevertheless, the spirit of Adonnino lived on within the EU, with the Parliament emerging as the new natural home for such a movement.

The Parliament's sporting agenda has a strong socio-cultural tradition. The Parliament has acknowledged that, above all, sport is a social pursuit. It not only carries health, educational, cultural and social implications, it can also be used for political purposes. In this connection, sport can aid the implementation of policy goals in other fields and can act as a vehicle through which the EU can connect itself to its citizens through the establishment of a people's Europe. For the Parliament, the expression of these goals is therefore generally considered a priority. Nevertheless, difficulties remain for the Parliament in their desire to advance the Adonnino agenda.

The most obvious barrier is the lack of a Treaty base for sport. This creates practical legislative and budgetary difficulties for the Parliament in terms of developing and funding sports-related initiatives. Elements within the Parliament's Committee on Culture, Youth, Education, the Media and Sport have been active in advancing the case for a Treaty Article on sport which would provide a legal base for legislation and guarantee a budgetary line.

The second major difficulty concerns the prevailing definition of sport adopted by the EU. Walrave, Donà and Bosman established sports economic link to the Treaty. As such, sport became a Single Market issue rather than a social issue. As the Parliament's Committee on Constitutional Affairs concluded,

although, it is a good idea that the Union should intervene to tackle a number of very specific problems in the sphere of sport, such as the fight against doping, it is absurd that such measures should be based on the Union's responsibility for the internal market, which results, for example, in ill advised case law such as the Bosman judgement. ${ }^{3}$ 
The difficulty in attempting to achieve the wider goal of constructing a European federation based solely on economic integration without a commitment to socio-cultural (political) integration is widely acknowledged by many MEPs.

Third, along with the other EU institutions, the Parliament has also had to confront the issue of how to disentangle sports economic function from its social function. Whilst the Parliament primarily sees sport as a social pursuit, it has acknowledged that sport carries out an economic function. The Parliament has had to balance the desire to protect sporting structures from the scope of EU law with the need to protect the rights of workers and consumers within the EU. For example in 1989 the Van Raay report condemned the use of nationality restrictions and the international transfer system. ${ }^{4}$

\section{The Larive report on the European Community and sport ${ }^{5}$}

The 1994 Larive report was the result of a number of sports-related reports stemming from the Parliament. These reports included 'Sport and the Community', 'Women in Sport', 'Vandalism and Violence in Sport' and 'Sport in the European Community and a People's Europe'. ${ }^{6}$ The Committee on Culture, Youth, Education and Media was responsible for the report with Mrs J. Larive MEP as rapporteur. The catalyst for the report was a motion for a resolution proposed by Mrs Ewing MEP on the protection of popular sporting traditions in Europe. This motion for a resolution sought ways to protect traditional sports from the deleterious consequences of the break up of local communities. Ewing called for the implementation of a framework of law to assure the legal recognition of these traditional games in Europe and the establishment of a body to study, safeguard and promote Europe's sporting traditions. ${ }^{7}$

The report included within its terms of reference a number of motions for resolutions that had been referred to it. The first motion for a resolution, written by Mrs Banotti MEP on the 'Need to Reappraise the EC's Sports Policy' called on the Commission to rethink its approach to sport in the wake of the approved Adonnino report, 1985. In particular, Banotti called into question funding priorities and asked for greater emphasis to be placed on a 'Sport For All' policy that could contribute to the creation of a true 'people's Europe'. ${ }^{8}$ The second motion for a resolution was provided by Mr Gutiérrez Díaz MEP in October 1991 on safety in professional boxing. ${ }^{9}$ The third motion suggested that a common logo should be worn by athletes from the 12 Community member states taking part in the Barcelona Olympic Games. ${ }^{10}$ Written by Mrs Muscardini MEP, the motion recognised the symbolic significance of sport and sought to use this to promote European integration. The common logo would, according to Muscardini, symbolise the athletes membership of the EU as an ideal and unified homeland and as an appeal for democracy for all the people's of Europe. The fourth motion for 
a resolution related to the outlaw of symbols that incite violence in sport. ${ }^{11}$ The authors of the text called on the Commission to assess the situation relating to anti-social practises in sport such as the actions of abusive and racist supporters and the use of totalitarian symbols in sport and take the necessary steps to promote effective legislation that will restore the full harmony and value of sport. The motion sought measures to protect those values in sport that encourages coexistence, understanding and tolerance among peoples, races and cultures. The final motion for a resolution concerning safety of sports installations was written by Mrs Muscardini MEP following the death of a number of fans due to the collapse of a temporary stand in Bastia, France. ${ }^{12}$

The Larive report clearly links the active or passive participation in sport with the social and cultural identity of people. Additionally, this participation has generated significant amounts of economic activity. Accordingly, the report argued that sport should receive political attention in the EU, first in relation to underpinning the process of European integration and secondly in connection to the operation of the Single Market.

The first area covered by the report concerned the relationship between EU legislation and the internal rules of sports organisations. The report challenged the mismatch between the rhetoric of the fundamental freedoms and the practise of sports organisations. Many of the issues raised in the report relating to restrictive practices in sport were dealt with in Bosman. Four subdivisions of legislative activity were identified. First, in relation to free movement of persons and services legislation, the report sought to ensure sport for all EU citizens regardless of nationality (a challenge to the use of nationality quotas in sport), the freedom to join and leave sports clubs (a challenge to the rules on transfer of players), the mutual recognition of coaches' diplomas and the freedom to conclude cross-border insurance contracts. Second, concerning free movement of goods legislation, the report commented that the internal market had clarified the position with regard to the cross-border movement of sports goods through VAT Directives, standardisation of technical specifications and issues relating to the composition of sports food. Third, the report commented on how EU rules on competition greatly affect the operation of sport in Europe. Fourth, the application of other general legislative provisions were examined including legislation on animals in sport and the protection of minors. Despite a concern for sportspersons to be afforded the same level of protection under EU law as any other EU citizen, the report was clear that the liberalisation of sporting rules should be accompanied by more socio-cultural measures.

The second main area dealt with by the Larive report concerned the role of the EU in encouraging active participation in sport. The report highlights the job-creation potential of sport, suggesting over 60 million people in the EU (12) belong to sports clubs with tens of million more taking part in sport in a recreational, non-organised way. However, the report suggested that this 
participation is highly uneven. In this connection, the report urged the EU to encourage a wider participation in sport to include the underprivileged, the disabled and women. Furthermore, participation in sport was identified as a useful tool for counteracting crime, health problems and worker absenteeism. School sport was therefore encouraged, as was the participation of the wider working and non-working population.

Third, the report addressed the issue of combating hooliganism in sport. In addition to raising the profile of fair play campaigns in sport in order to combat 'on-the-field' problems, the report suggested that 'off-the-field' problems such as hooliganism can be dealt with via legislation. In particular, stadium structure and layout specifications can help minimise disorder. Support was given to national measures designed to minimise hooliganism, although it was stressed that nationality should not be used as a reason for refusing or impeding access to sporting events.

The final area dealt with by the report concerned the use of sport in fostering a European identity. The report criticised the EU approach of sponsoring large-scale sporting events with high media interest, questioning the appropriateness of the use of financial resources. Implicitly, the report suggested that this amounts to marketing the EU, whereas the EU should be involved in smaller, more specific projects that are of more relevance to EU citizens. In this respect, the report welcomed the Commission's policy shift on sport which proposed a change in this direction. The report argued that funding priority should be given to small-scale, cross-border projects as this heightens people's awareness of other cultures. In addition, support for national and regional traditional sports should be encouraged as means of protecting traditional sports. The report suggested that one mechanism for advancing the aim of fostering a European identity through sport is to integrate sport into the operation of other Community projects such as the European Regional Development Fund, the European Social Fund, town twinning schemes, the Interreg programme and the Youth for Europe initiative. The report also stressed the importance of European support for sports facilities, European training programmes and sports research/ management initiatives. To help co-ordination in these areas, the report also suggested that sport should be included as an area of formal competence in the Treaty.

\section{The Bosman setback 1995-1997}

The 1995 Bosman ruling represented a set back for many socio-cultural actors despite the Larive report's desire to see the lifting of restrictions placed on the movement of sportsmen and women. Bosman confirmed the predominance of the EU's market-based definition of sport at the expense of the social definition. In short, the Bosman approach was inconsistent with the Adonnino agenda. 
The Pack report on the Role of the European Union in the Field of Sport ${ }^{13}$ In June 1996, the Parliament's Committee on Culture, Youth, Education and the Media, appointed Doris Pack as rapporteur to a report on the role of the $\mathrm{EU}$ in the field of sport. Additionally, it was decided to include in the report a motion for a resolution on setting up a European youth sport fund. As with the Larive report, the report reviewed the significance of the sports sector to Europe's society and economy. In terms of participation in sport, the report claimed that over 100 million European citizens participate in sporting activity and that tens of thousands of sports associations organise these activities. As such, sport 'constitutes a basic cultural and social phenomena' ${ }^{14}$ Sport is therefore crucial to European society given that access to it promotes 'personal development and a well balanced personality'. ${ }^{15}$ In this connection the report therefore draws similarities between the sports sector in Europe and the cultural world. Furthermore, the report argues that the love of sport extends beyond participation to those who are not actively involved. As such, the report recognises the importance of ensuring citizens gain access to sporting events and information on them. The emphasis on social interaction is supplemented with a focus on sport as a method of countering the deleterious effects of smoking, alcohol and drug abuse and a preventative weapon against potential health problems such as cancer and cardiovascular problems. Sport therefore has a role to play in the field of physical and mental health and social interaction.

The report also emphasised the economic significance of the sports sector in Europe. According to the report sport generates an estimated 1.5 per cent of the EU's gross domestic product (GDP) and plays a significant role as a source of employment. Even though the report welcomed the ECJ's lifting of restrictions on the mobility of sports men and women in Bosman, it claimed that,

although the European Union has taken an interest in professional sport as an activity, it has, to date, only taken account in a very marginal fashion of the cultural, educational and social dimension of sport, and whereas such neglect stems basically from the fact that there is no explicit reference to sport in the Treaty. ${ }^{16}$

Accordingly, activity in the sports sector has been economically motivated and not specifically directed at sport. The report therefore called on the intergovernmental conference (at the time still sitting) to include a reference to sport in Article 128 (Culture) of the revised Treaty (the Amsterdam Treaty) or to establish a separate Article for sport. The report does, however, express the opinion that sport should not be exempt from EU law and places a degree of pressure on sports organisations to ensure that the solidarity of sport is maintained. In this connection, the report suggests financial redistribution between sports organisations as an effective mechanism to achieve this solidarity. 
This general lack of interest in the socio-cultural dimensions of sport is illustrated by the size of the Community budget for sport. The ECU 3 million 'Sport in Europe' programme (Article B3-305 in the 1997 Community budget) was created by the Parliament and (at the time) financed programmes such as the Eurathlon programme and sports initiatives for the disabled. Only through the activities of the Committee on Culture, Youth, Education and Media and the Committee on Budgets in the Parliament was this expenditure included in the budget. The report criticises the Commission for continually failing to include this programme in its preliminary draft budget. The Commission included Article B3-305 in the chapter entitled 'Information and Communication' within the preliminary draft budget. The report argues that this is 'symbolic of the subsidiary, workaday role ascribed to it by the Commission, which sees it simply as a means of communication' ${ }^{17}$ Furthermore, the report argues that this attitude demonstrates that sport is not considered by the EU on its own merits, but rather as a means of implementing other policies. The report sees a clear division between the rhetoric of a people's Europe and the practise of how sport is dealt with by the EU.

The report recommended that the Commission should establish a task force to examine more closely the relationship between the EU and the European sports sector. A Green Paper should then be produced with a view to elaborate the themes stemming from this task force. The report expressed the view that all dimensions of sport, not just those relating to it as an economic activity, should be taken into consideration. The report also commented that pending the implementation of that action plan, sports initiatives could be promoted through other channels such as the EU's regional and social policies, those concerning education, training and youth exchanges, equal opportunities policy, anti-racist policies and research policies. To ensure some action in these directions, the report also called for the convening of a Council of Ministers for Sport and, to ensure visibility, called for a European Year of Sport.

The Motion for a Resolution relating to the establishment of a European youth sport fund called on the Commission to enter a specific appropriation in the forthcoming budget for youth sport and also to oversee the establishment of a youth sport fund, a solidarity fund paid into by sporting organisations. Additionally, the Resolution called on the Commission to co-operate with member states and European sports bodies to draw up an action programme for youth sport.

In essence the Pack report reflects the more socio-cultural tendencies within the Parliament. The report stresses the multi-dimensional nature of sport, rather than the narrowly economic interpretation applied by the ECJ and the Competition Policy Directorate. In effect, the report seeks the establishment of a European sports policy. First, the report wants sport to be granted a Treaty base. Second, the report wants a more co-ordinated 
approach to sport to be adopted by the Commission through the adoption of a Green Paper. Third, the report seeks more creative ways of feeding sports initiatives into other programmes. Fourth, the report calls for more funding for sports initiatives and, finally, the report seeks the establishment of a Council of Ministers for Sport. The Parliament is therefore attempting to act as a counterweight in the European policy process to the more marketbased motivations of the Commission. Furthermore, the Parliament has signalled, through its budgetary powers and the report that it intends to creatively promote the socio-cultural elements of sport through other policy means. A clear example of this was demonstrated by the inclusion in the revised Television Without Frontiers (TWF) Directive of Article 3a dealing with the broadcasting of sporting events on free-to-air television. This conforms to the general approach of the Parliament, which has traditionally sought to expand the EU's agenda through the creative exploitation of institutional powers.

\section{The Television Without Frontiers Directive}

It has already been established by the ECJ that television broadcasts are to be defined as tradable services within the meaning of Articles 49 and 50 of the Treaty. ${ }^{18}$ The primary mechanism through which the EU has sought to establish the legal conditions necessary to establish a common market for these broadcasting services in Europe has been through the TWF project. Based on Articles 47 (2) and 55 of the Treaty, the project's provisions on sporting broadcasts represent something of a contradiction. In theory, member states cannot restrict the transmission of services emanating from another member state, yet the amended TWF Directive permits the establishment of such restrictions in sports broadcasting through the creation of national lists to protect major events. Article $3 \mathrm{a}$ of the Directive permits member states to draw up lists of protected sporting events that will have to be made available to the public on free-to-air television. Such a restriction on broadcasting services has been defended on the grounds of public interest but must be of non-discriminatory nature and must be proportionate to their objectives. The ECJ has confirmed the validity of public interest arguments in the broadcasting sector. ${ }^{19}$

The TWF Directive resulted from a series of measures adopted by the EU institutions in the field of broadcasting and audio-visual policy (Collins 1994, Humphreys 1996). EU involvement in broadcasting and audio-visual policy had its roots in the early 1980s. The 1982 Hahn report expressed the view that television and the mass media in general could aid the process of European integration through its ability to shape public opinion. Hahn, a German Christian Democrat MEP, argued that political integration in Europe would be difficult to achieve whilst the media remained nationally controlled. The report emphasised how new technology would radically transform the nature of broadcasting in Europe, calling into question 
traditional nation state forms of broadcasting. The Parliament adopted the Hahn report through a resolution (the Hahn Resolution). As a result of this resolution, the Commission produced an interim report titled, 'Realities and Tendencies in European Television: Perspectives and Options'. A year after the publication of DG X's interim report, the Commission produced a 1984 Green Paper on the 'Establishment of the Common Market for Broadcasting, Especially by Satellite and Cable', better known as Television Without Frontiers. ${ }^{20}$ Significantly, responsibility for preparing the Green Paper lay, this time, with the more liberal DG III and references to the cultural dimension of broadcasting were kept to a minimum. In light of the Commission's overtly economic justifications, the TWF proposal represented a significant break with the Hahn report and 'Realities and Tendencies'.

In order to realise a common market in broadcasting, the Commission's Green Paper proposed harmonisation in three areas: advertising, copyright and public order, personal rights and the right of reply. The TWF Directive was agreed in Council by a qualified majority in October 1989 and came into operation two years later. However, many supporters of the Hahn report and 'Realities and Tendencies' were disappointed with the new TWF Directive as it was not a true reflection of the spirit of Hahn. Similar arguments were advanced a number of years later concerning the compatibility of Bosman with the Adonnino sporting agenda.

Built into the Directive was provision for review after five years (Article 26). The Commission presented their proposals for review on 31 May 1995. This review gave the Parliament an opportunity to not only re-kindle some of the spirit of Hahn, but also to seek to balance the economic definition of sport adopted in Bosman with a socio-cultural sporting measure. The Parliament's ability to do this was enhanced by the new co-decision procedure for agreeing legislation. ${ }^{21}$ In accordance with this procedure the Parliament completed its first reading of the proposal on 14 February 1996 by approving the Commission's proposal subject to amendments. The Council adopted a common position on 8 July 1996 and the Parliament held its second reading on 12 November 1996. A final text was agreed between the Parliament and Council in April 1997 after discussions in the conciliation committee. Member states had until December 1998 to transpose the new Directive into national law.

The new Directive made some minor definitional amendments to the original Directive in order to make it more workable. However, the most significant change came in the form of a Parliament amendment designed to guarantee public viewing access to major sporting events on television. Amendment number 20 was agreed by the Parliament during its second reading of the revised Directive. ${ }^{22}$ To give effect to the Parliament's amendment, Article 3a was included in the new Directive. The purpose of Article 3a (full text below) was explained in recital 18 of the new Directive. 
Recital 18: 'Whereas it is essential that member states should be able to take measures to protect the right to information and to ensure wide access by the public to television coverage of national or non-national events of major importance for society, such as the Olympic games, the football World Cup and European football Championship; whereas to this end member states retain the right to take measures compatible with Community law aimed at regulating the exercise by broadcasters under their jurisdiction of exclusive broadcasting rights to such events'.

\section{Article $3 a$}

1 Each member state may take measures in accordance with Community law to ensure that broadcasters under its jurisdiction do not broadcast on an exclusive basis events which are regarded by that member state as being of major importance for society in such a way as to deprive a substantial proportion of the public in that member state of the possibility of following such events via live coverage or deferred coverage on free television. If it does so, the member state concerned shall draw up a list of designated events, national or non-national, which it considers to be of major importance for society. It shall do so in a clear and transparent manner in due and effective time. In so doing the member state concerned shall also determine whether these events should be available via whole or partial live coverage, or where necessary or appropriate for objective reasons in the public interest, whole or partial deferred coverage.

2 Member states shall immediately notify to the Commission any measures taken or to be taken pursuant to paragraph 1 . Within a period of three months from the notification, the Commission shall verify that such measures are compatible with Community law and communicate them to the other member states. It shall seek the opinion of the Committee established pursuant to Article 23a. It shall forthwith publish the measures taken in the Official Journal of the European Communities and at least once a year the consolidated list of the measures taken by member states.

3 Member states shall ensure, by appropriate means, within the framework of their legislation that broadcasters under their jurisdiction do not exercise the exclusive rights purchased by those broadcasters following the date of publication of this Directive in such a way that a substantial proportion of the public in another member state is deprived of the possibility of following events which are designated by that other member state in accordance with the preceding paragraphs via whole or partial live coverage or, where necessary or appropriate for objective reasons in the public interest, whole or partial deferred coverage on free television as determined by that other member state in accordance with paragraph $1 .^{23}$

Article $3 \mathrm{a}$ of the Directive therefore permits member states to draw up lists of protected sporting events that will have to be made available to the public on free-to-air television. These lists are then notified to the Commission who must seek the opinion of the so-called 'Contact Committee' composed of representatives of all member states and assess the compatibility of the national measures with EU law. Measures approved by 
the Commission are published in the Official Journal of the European Communities.

In Britain, the Broadcasting Act of 1996, as amended by the Television Broadcasting Regulations 2000, implements the Directive. Part 4 of the Act governs the listing of 'Sporting and Other Events of National Interest'. Section 97 allows the Secretary of State to establish a list of sporting (or other) events of national interest. Sections 98-101 ensure public viewing accessibility to these listed events. Currently in Britain the following events are listed: (Group A): The Olympic Games, the FIFA World Cup Finals Tournament, the FA Cup Final, the Scottish FA Cup Final (in Scotland), the Grand National, the Derby, the Wimbledon Tennis Finals, the European Football Championship Finals Tournament, the Rugby League Challenge Cup Final, the Rugby World Cup Final. (Group B): Cricket Test matches played in England, non-finals play in the Wimbledon Tournament, all other matches in the Rugby World Cup Finals Tournament, Six Nations Rugby tournament matches involving home countries, the Commonwealth Games, the World Athletics Championship, the Cricket World Cup - the Final, Semifinals and matches involving home nations', the Ryder Cup, the Open Golf Championship.

The justifications in support of Article 3 a tend to reflect socio-cultural tendencies inherent within the Parliament. Furthermore, they represent an exception to the general principle of free movement of services in transfrontier broadcasting enshrined in the TWF Directive. The first justification relates to the concern that the drift towards pay-TV television denies the sporting public the opportunity to watch sport on television. As such major sporting events that are of particular significance to society should be protected (the 'public interest'/'national heritage' argument).

Second, as the original TWF Directive recognised, national media sovereignty no longer fully exists. As such purely national measures designed to ensure unencrypted access would be prone to circumvention by operators external to national jurisdiction. If it is the wish of national authorities to ensure public access to televised major events, then the EU offers an appropriate level of protection given technology driven developments in transfrontier broadcasting.

Third, given the high level of competition between broadcasters and the small size of potential lists, income to sporting clubs will not be excessively restricted by regulation.

Fourth, as commercial television operators have identified, sport is an important component to schedules due to its popularity. If public service broadcasters are denied major sporting events it may threaten their overall survival in the market place. If this happens, a source of competition will be denied. This argument may however over emphasise the importance of sport to public service broadcasters.

Fifth, by protecting the broadcasting of major sporting events, the EU can 
demonstrate a degree of visibility and relevance to Europe's public in a manner compatible with historical attempts to create a 'people's Europe'. This approach would be consistent with the general theme of the Hahn report relating to information, media and European integration and indeed the Adonnino Committee's central thrust. It reflects a socio-cultural inspired attempt to redress the market-based approach adopted in the first TWF Directive and the ruling in Bosman.

Nevertheless, the Directive goes against a trend in European sport favouring a free market in broadcasting. The arguments are essentially economic. Although free-to-air broadcasting increases viewing numbers, it denies the sporting organisations the ability to realise the full value of their rights. The (as then) Sports Council of Great Britain changed its policy on sports broadcasting to embrace the free market. Until February 1996 the Sports Council supported the listing of designated sporting events. Since this date they have favoured a free market in sports rights thus allowing them to maximise income from their sale. The English football Premier League shares these concerns pointing to the unsatisfactory state of terrestrial broadcasting of sport in the 1980s which limited competition for rights and restricted sports broadcasting income. Revenue generated from television money has enabled English football to invest in new and improved stadiums, better facilities for fans and players and grass roots investment into youth football. As such, it is the view of many European sporting organisations that they are in the best position to make distributional decisions concerning investment in sport and so should be left free to negotiate appropriate broadcasting contracts with a range of operators. The case against regulation of sporting broadcasts is naturally shared by the cable and satellite operators who often require exclusive sporting broadcasts to attract new subscribers.

\section{The Amsterdam breakthrough 1997}

The Parliament's response to the ruling in Bosman proved influential in highlighting and articulating the concerns of the socio-cultural advocacy coalition. In particular, the Parliament emerged as an important forum through which demands for the incorporation of sport into the Treaty emerged. Although the Parliament's activity pressurised the member states into taking action, the Parliament's socio-cultural agenda tapped into a thread of concern already evident within some national capitals. Not only had the member states agreed to the Adonnino proposals, but following unsuccessful governmental submissions to the ECJ in Bosman, a growing number of member states including the Italian, Belgian, French and German governments gave their support to sport's Treaty incorporation. As such, the Parliament's role must be placed in context. Alone, the Parliament lacked the legislative powers to pursue a more holistic approach to sport. Therefore without member state support, the Parliament would have been unable to force the issue of sport on to the European Council's agenda. 
Although the TWF Directive was a success for the Parliament, the ECJ's ruling in Bosman and the approach adopted by the Commission in applying competition law demonstrated to the socio-cultural coalition the insensitivity with which the EU dealt with sporting issues. The perception was that the EU was not only failing to recognise the social importance of sport, but it was also curtailing sporting 'autonomy'. A Treaty Article was therefore required in order to address these two concerns. As a result, in the run to the Amsterdam Summit, intense lobbying took place for the adoption of an Article for sport in the newly revised Treaty. In particular, the maximalist members of the socio-cultural coalition hoped to ensure greater protection for sports rules from the application of EU law whilst also granting sport a legal base to exploit funding opportunities.

Calls for an Article for sport came to a head at the 6th European Sports Forum where representatives of the National Olympic Committees of the 15 member states and 30 international and European sports federations supported sport's inclusion into the Treaty. Support was also forthcoming from the Parliament, yet crucially not the Commission who wanted to avoid the setting of a precedent for allowing certain professions exemptions from the Treaty and also for fear of sparking inter-DG conflict over the approach to sports policy (European Voice 1996). A draft for an Article on sport in the Treaty was agreed by representatives of ENGSO and the EOC's. Its contents give an insight into the objectives of the drafters.

1 The European Community contributes to the development of sport in its member states, taking strict account of the diversity of its public and private structures as well as of the competence of its member states and of the autonomy of sporting organisations with regard to the organisation of sport and its rules. The Community's activities (proceedings) take into account the integrationist qualities of sport within the framework of Europe, its citizens and social dimension.

2 The Community's activities (proceedings) encourage co-operation between organisations responsible for sport in the member states, and fulfil their activities in the following domains:

- promotion of exchanges between European citizens through the integrationist qualities of sport. These exchanges should contribute to a better knowledge and acceptance of the social and cultural differences between member states.

- encouragement of participation in sport, as a means of promoting the health of European citizens.

- support of sporting activities for social ends, aiming to combat unemployment and discrimination, racism and violence, by promoting equal opportunities between men and women.

- help for sporting initiatives in the realm of education, as much at the level of management training and sports technicians as in the creation of exchange programmes for professions linked to sport. European sporting co-operation founded on sporting institutions and mutual information 
on training systems and sporting organisations will be particularly encouraged.

- support for projects aimed at the states of Central and Eastern Europe and projects aimed at co-operation for development.

3 The Community and its member states encourages co-operation with countries outside the Community and with international organisations responsible for sporting matters, particular the Council of Europe.

4 The Community takes into account aspects related to sport in policies conducted on the basis of other clauses of the present Treaty.

5 In order to contribute to the realisation of the objectives set out in the present article, the Council:

- acting according to the procedures of articles $189 \mathrm{~b}$ (co-decision) and after consultation with the Committee of the Regions, adopts measures of encouragement to the exclusion of all harmonisation of legal and administrative clauses of the member states. The Council decides by unanimity according to article $189 \mathrm{~b}$.

- adopts by unanimity the recommendations, as proposed by the Commission.

This ENGSO/EOC memorandum was sent to all representatives on the Reflection Group (the group responsible for managing the Amsterdam IGC process and consisting of representatives of national administrations, the Parliament and Commission). Such an Article would ensure that EU action in the field of sport would reflect the social dimension of sport whilst securing the right for sport to be taken into consideration in the framing of other EU policies. Furthermore, by ensuring that the co-decision procedure applied, the widest possible consultation would have been guaranteed. The independent Treaty Article approach was just one approach considered by members of the socio-cultural coalition. Alternatives included adding sport to the list of EU activities outlined in Article 3 of the Treaty, adding sport to Article 151 (ex 128) dealing with cultural policy and the greater use of soft law measures by the member states. The next chapter examines these proposals in greater depth.

The eventual appearance of sport in the Amsterdam Treaty came as a surprise despite the prevailing political climate in which Amsterdam was negotiated. Following the traumatic ratification of the Maastricht Treaty, it was widely expected that the EU would adopt measures in the new Treaty that would attempt to bring Europe's citizen's closer to the EU. Sport was considered one such issue through which the EU could achieve this objective. Despite this, sport was not mentioned in draft versions of the Treaty and was not included on the formal agenda of the Reflection Group. It was reported that when challenged on the omission of sport in an early draft of the Treaty, Irish officials (at the time holding the Presidency) claimed that no member state had raised the issue (European Voice 1996). Furthermore, the Commission was also reluctant. Nevertheless, following the conclusion of 
the 1996/1997 intergovernmental conference process, the Heads of State and Government of the member states meeting in Amsterdam attached a non-binding Declaration to the Treaty. The Declaration read:

The conference emphasises the social significance of sport, in particular its role in forging identity and bringing people together. The conference therefore calls on the bodies of the European Union to listen to sports associations when important questions affecting sport are at issue. In this connection, special consideration should be given to the particular characteristics of amateur sport. ${ }^{24}$

Through the Declaration, the EU has formally acknowledged the social and integrationist qualities of sport even though, as a soft law measure, it has not legally committed itself to supranational action and therefore expenditure. The EU has however given a commitment that sport is to be taken into account when other EU policies are being adopted. To facilitate this, the EU has also committed itself to consult with sporting bodies. This has had the effect of further formalising and institutionalising the relationship between sport and the EU. Nevertheless, the result disappointed those who wanted the EU to adopt more formal measures. However, although Declarations have no formal legal status in the EU, their significance must not be underestimated. Soft law refers to rules of conduct which, in principle have no legally binding force but which nevertheless may have a significant effect on policy development. Soft law has the potential to produce significant effects. First, it is not uncommon for soft law to be used as quasilegal justification by $\mathrm{EU}$ institutions for the development of policy initiatives. The Amsterdam Declaration was subsequently referred to by all the EU institutions, including the ECJ, in connection with sporting activity. Soft law therefore has the potential to harden over time. Second, the use of soft law is often a tactic used by the European Council and Council of Ministers when they are unable to agree upon binding measures but nevertheless wish to place political pressure on the EU institutions for a change in policy direction. Soft law can be employed by the member states as an implied threat of taking further harder measures unless EU institutions change their approach. As such, it has offered some guidance as to the interpretation and scope of application of EU law.

\section{The re-assertion of socio-cultural ideas: the birth of the new approach 1998-}

The Amsterdam Declaration added impetus to the socio-cultural agenda whilst also equipping them with an additional institutional venue to exploit. Their agenda took giant strides after 1998. Out of the confusion and ambiguity of the Bosman ruling emerged (is emerging) a more holistic and coordinated approach to sports policy. This 'new approach' has been forged through an alliance between the member states and the Education and 
Culture Directorate. The member states have responded to pressure for a change of approach promoted by the Parliament by piecing together a series of policy guidelines on sports policy through a combination of soft law measures. In addition to Treaty Declarations, soft law refers to Presidency Conclusions and intergovernmental political guidelines. The Education and Culture Directorate has responded to these soft law developments by establishing a framework for the development of a EU sports policy. At the heart of this framework lies a more broad-based definition of sport which has brought into the development of EU sports policy many ideas supported by the socio-cultural coalition.

\section{Initial Council Presidency conclusions 1997-1998}

Prior to the Amsterdam Declaration, it was rare for the European Council to discuss sport. Since Amsterdam, it is rare for the member states not to discuss it in some intergovernmental forum. Initially, following the Amsterdam Treaty, sport was discussed as a vehicle through which unemployment could be tackled. This was partly the concern of Luxembourg's Presidency in the second half of 1997 and reflected a desire to follow up the employment provisions contained within the Treaty.

The British Council Presidency in the first half of 1998 continued the theme of examining sport in conjunction with employment but expanded its scope to examine the wider issue of how sport in Europe could be used to combat social exclusion and regenerate communities. A paper was prepared on this issue and discussed at a troika meeting of EU Sports Ministers in Twickenham in April 1998. Present at the meeting were representatives from the British, Luxembourg and Austrian governments and two representatives from DG X of the European Commission (now the Education and Culture Directorate).

The meeting discussed two topics. The first was how to build on the Amsterdam Declaration on Sport. In this connection, the Ministers identified four important issues for the Commission to take into consideration. First, a clear distinction needs to be made between amateur and professional sport. Second, this needs to inform the debate on the relationship between employment and EU law, particularly given the nature of the (as then) unresolved Deliege case. Third, this also feeds into the issue of freedom of movement for sportspersons between EU member states. Finally, the Declaration has implications for EU funding to professional, as opposed to, amateur sport.

The second topic for discussion concerned the Commission's preparation of a Green Paper on Sport. The Commission anticipated the Paper to include a focus on the structure ('model') of European sport, the role and importance of television in sport, the social dimension of sport and, following the Commission's 'First Report on Local Employment and Development Initiatives', the relationship between sport and employment. The Ministers indicated a number of themes that they believed the Paper should address. 
These included improved co-ordinating mechanisms between bodies involved in sport, measures designed to tackle social exclusion and unemployment and an examination of the way European law affects sports organisations throughout Europe. ${ }^{25}$ In the event, the Green Paper idea was replaced with a Commission working paper and consultation exercise (see below).

In a wider forum at the Cardiff European Council meeting of 15/16 June 1998, sport was mentioned in the Presidency Conclusions. Under the heading of 'Bringing the Union Closer to the People', the European Council invited the Council and member states 'to consider ideas to promote more contacts between young people, e.g. through the internet, and the scope for tackling social exclusion among young people, including sport' ${ }^{26}$ The spirit of Adonnino had returned.

\section{Commission working paper: 'The Development and Prospects for}

Community Action in the Field of Sport, September 1998'29

In addition to intergovernmental developments, 1998 also saw the emergence of a more co-ordinated Commission response to the Amsterdam Declaration. The main contribution made by the Education and Culture Directorate to the establishment of a EU sports policy has come in its capacity as the initiator of sporting proposals and consultation documents. In essence, it has attempted to steer a middle course between the post-Bosman forces of Single Market regulation and the socio-cultural agenda.

In September 1998 as part of its response to the Declaration on Sport annexed to the Treaty of Amsterdam, DG X published a Commission working paper entitled 'The Development and Prospects for Community Action in the Field of sport'. The paper identified sport as performing an educational, a public health, a social, a cultural and a recreational function. Although the paper addressed the economic function of sport, it represents an attempt to advance socio-cultural goals. In this connection, the paper represents a continuation in thinking from the Adonnino, Larive and Pack reports.

The introduction to the paper tentatively raises the underlying problem facing the EU in relation to the sports sector. Whilst sport accounts for 3 per cent of world trade, one European in three is actively involved in a sport and there are 545,000 sports clubs in the Community. In other words, sport represents a significant element of the European economy, but it also performs a crucial social role in European society. The more sport, in particular professional sport, is practised as a truly economic activity, so general EU legislation will become applied to the sports sector.

The working paper identifies three major areas of EU activity that particularly affects sport. The first is freedom of movement. The application of Article 39 in the Bosman case is the clearest example of this relationship. The second area relates to competition policy and audio-visual policy. These 
areas have an impact on how sport is televised in Europe. The third area concerns the application of other general EU policies such as health, education, vocational training and the environment. The paper also stresses how sport can be used as a tool for combating social exclusion and a source of voluntary work in Europe.

In the second section of the working paper, a general review of EU institutional involvement in sport is provided. The activities of the Court, Commission, Parliament and Council have all had an affect on the operation of sport in Europe.

The third section examines the 'positive effects' of sport and some problems facing European Sport. The paper acknowledges the difficulties in attempting to define sport. In the paper, the Commission employs the Council of Europe's definition of sport contained in the European Sports Charter. This defines sport as 'all forms of physical activity which, through casual or organised participation, aim at expressing or improving physical fitness and mental well being, forming social relationships or obtaining results in competition at all levels ${ }^{28}$ The paper argues that sport performs an educational function, a public health function, a social function, a cultural function and a recreational functional. However, the paper then proceeds to define sport in economic terms as well. Sport sponsorship generates US $\$ 15$ billion, the sale of television rights US\$42 billion and ticket sales US\$50 billion. Furthermore, the European share of sports trade is 36 per cent, second only to the USA with 42 per cent. ${ }^{29}$ Faced with these twin definitions of sport, the working paper represented a first significant realisation that the EU must find a satisfactory way of regulating the economic dimension of sport through the application of general EU policy to the sports sector, whilst recognising and indeed harnessing the 'positive effects' of sport.

Before addressing the specifics of EU involvement in sport, the working paper reviewed some of the problems and challenges facing European sport. Three issues are covered; the risk of excessive commercialisation, the lack of protection for young people taking part in top-level competitions and the ineffectiveness of anti-doping measures. In relation to commercialisation, the International Olympic Committee's decision in the 1980s to remove the distinction between amateurs and professionals at the Olympic Games and to allow the Games to be commercially sponsored, was a significant move towards commercialising sport. Commercialisation can potentially break the solidarity between professional and amateur sport.

In the fourth section, the paper addressed the specifics of EU action in sport. In particular, the issue of the economic regulation of sport was dealt with. The paper identified three key relationships between the EU and the sports sector in this regard. The first is the relationship between sport and television. The second relates to sport and competition policy and the third concerns matters relating to the 'freedoms' enshrined in the Treaty. 
Having reviewed how EU policies affect the operation of sport, the paper examined how sport can be applied to general policy as 'various Community policies are excellent instruments for demonstrating to sporting interests the additional benefits of Community action' ${ }^{30}$ Using the Declaration in the Amsterdam Treaty as justification for greater targeted action in sport, the paper called for a strategy on sport. Areas targeted by the paper included; public health, protection of young workers, safety at sports facilities, standards for sports equipment, the free movement of sports equipment, veterinary regulations concerning animals in sport, scientific and technological research, tourism, taxation and sport, sport and the environment, education and vocational training and sport for people with disabilities.

The paper also argued that sport could be integrated into the EU's wider external relations 'policy'. In this connection, sport can either be used to put pressure on third countries in the form of sanctions, or be used to help support developing countries. In the case of the latter, the paper sees the Lomé Convention as an appropriate mechanism to achieve this aim.

The paper's conclusion confirms the dual approach embodied in the document. On the one hand the EU, and in particular the Commission, will continue to implement EU law whilst on the other, sport will be increasingly integrated into other EU policies. As the EU lacks a Treaty competence to formulate a sports policy, the latter approach may be used as a framework for a future EU policy in sport.

\section{'The European Model of Sport', Commission Consultation Document, November $1998^{31}$}

Following the working paper on sport released by DG X in September 1998, the Commission (DG X) published a consultation document on the same subject later in the same year. The document reveals that at the time of publication, the Commission had received 55 sports-related complaints. In accordance with the guidelines contained in the Declaration on Sport annexed to the Treaty of Amsterdam, the Commission stated that its central aim was to provide assistance to sports organisations seeking to re-frame sporting rules in line with EU law. To achieve this, the Commission published the consultation document as a mechanism through which the European sports sector could express their opinions on the nature of the rapidly developing relationship between sport and the EU. The results of this consultation exercise were to be used first to prepare for the European Conference on Sport (Assises Européennes du sport) held in May 1999 and second to identify more clearly the 'real' features of European sport and to preserve them.

The Commission used the exercise as a stock-taking measure. As the working paper identified, not only is sport practised as a significant economic activity, but sport possesses socio-cultural and integrationist qualities that may well be worth preserving. A framework flexible enough to 
accommodate both characteristics yet compatible with EU law thus was being prepared. The consultation document comprises three chapters. First, the document attempts to describe the organisation of sport in Europe. Second, the document reviews sport's economic context by examining the relationship between sport and television. Third, the document examines the social policy dimension to sport.

The chapter on the 'European Model of Sport' examined how sport in Western Europe has traditionally been organised on a 'mixed' model basis where the actions of governmental and non-governmental organisations have existed side by side. In addition, sport has operated in an environment dominated by public service television. Developments in broadcasting in the 1980s have fundamentally changed this environment. The document describes the model of sport in Europe as a 'pyramid structure'. This structure describes both the organisational and competitive dimensions to European sport. In organisational terms, the structure comprises European federations, national federations, regional federations and the clubs.

At the pinnacle of the pyramid exist the European federations. Usually, European federations will attempt to maintain their regulatory dominance by only permitting one national federation per country to be affiliated to it. Below the European federations lie the national sporting federations who are affiliated to the European federation. A national federation organises and regulates the sport in question within the national territory. The national federations represent their members within the European or international federation. In addition, they organise national championships. Below the national federations lie the regional federations who are responsible for organising regional championships or co-ordinating sport on a regional level. Underpinning the pyramid are the sports clubs. Dominating this level are amateur sports men and women and administrators who are unpaid. The sports clubs offer the opportunity to local people to become involved in sport. As such, the clubs perform an important social function.

The pyramid structure also describes the competitive balance in European sport. Movement up and down the pyramid is an essential part of sport in Europe. This is achieved through promotion and relegation. In many sports, qualification for European competitions is achieved through championship or cup performance. In essence therefore, the pyramid structure implies considerable interdependence between the levels. This 'open' model contrasts with the 'closed' procedures in the USA where championships are closed and sport is governed by many federations.

The European 'model' has emerged out of the traditional culture of amateurism in European sport whilst the US 'model' represents professionalism. In this respect, European sport has traditionally not been practised as an overtly economic activity whilst sport in the US has. However, this tradition is changing. Sport in Europe has been greatly internationalised and commercialised. This has led to a number of problems. First, due to the growing 
importance of negotiating television rights, sports federations have assumed the role of a commercial company. This may conflict with their role as a regulatory body. Second, clubs regulated by the federations are beginning to demand a greater share of television rights. This may in time lead to some clubs leaving the federation and establishing a breakaway structure. Third, a tension exists between the requirement of federations to act as commercial bodies whilst at the same time promoting grassroots sport. Fourth, the commercial developments in sport have resulted in sports organisations changing internal rules to accommodate EU competition law. Fifth, some investment companies have expressed an interest in purchasing football clubs. Federation rules regulating multiple ownership may conflict with EU competition rules. Finally, due to the rapid commercialisation of sport in Europe it is feared that only the commercially viable sports will survive.

Chapter 2 of the consultation document reviews the relationship between sport and television in Europe. Most of the issues raised in this connection have already been addressed elsewhere in this text. The chapter examines the importance of broadcasting rights to sports bodies and reviews some themes relating to this. First, who should own broadcasting rights, the federations or the clubs? Second, how should rights be sold, individually or collectively? Third, should rights be sold on an exclusive basis? Fourth, should television companies be able to purchase football clubs thus owning and exploiting broadcasting rights? Fifth, should some sports be broadcast on free-to-air television and, relating to this point, what is to be the future role of public television in Europe?

Chapter 3 examined the social dimension to sport. Six themes were identified. First, sport performs an educational function. In particular, sport promotes both competition and sense of fair play. Second, sport can be used as a means of social integration. In particular sport can act as a tool to promote more tolerant attitudes towards specific groups in European society such as ethnic minorities and the disabled. Third, sporting platforms can help promote an awareness of the environment. Fourth, sport is inextricably linked to public health as participation in sport is an important preventative weapon in the fight against ill health. Fifth, a major issue in European and world sport is doping. The document argues that the EU lacks competence to act in doping matters but action can be taken in the context of other policy areas (such as health) and in the forum of Justice and Home Affairs cooperation. Finally, sport plays a significant role in creating employment opportunities yet this needs to be balanced with the need to protect young participants in sport.

Both the working paper and the consultation document represent an attempt by the Commission to steer a middle course between Single Market and socio-cultural forces. Although competition rules are still to apply to the sports sector, a more soft touch approach is implied. At the same time, 
the socio-cultural dimensions of sport are being recognised through the integration of sport into other EU policies. As such, the Commission signalled a desire to develop a more broad-based approach to sport policy. This theme was continued by the member states at the end of 1999 and throughout 2000.

The Committee of Regions (COR) opinion on the Commission's report welcomed the broad thrust of the report, particularly the Commission's call to examine how the concerns of sport can be taken into account in the EU Treaty. ${ }^{32}$ Without an EU commitment to the social dimension of sport, the COR argued that sports role in forging a people's Europe risks being overlooked. As such, 'the COR considers that a European policy for sport should be developed with greater emphasis on the vital cultural and socio-economic role of sport in Europe'. ${ }^{33}$ Such a policy should involve introducing and developing 'by suitable changes to European legislation, a framework of conditions which will enable sport in European regional and local authority areas to fulfil its socially valuable tasks'. ${ }^{34}$

\section{The Austrian Presidency (July-December 1998)}

The Austrian Council Presidency continued discussions on the relationship between sport and the EU. Once again sport appeared in the Presidency Conclusions following the Vienna European Council meeting of 11/12 December 1998. Point XII read:

Recalling the Declaration on Sport attached to the Treaty of Amsterdam and recognising the social role of sport, the European Council invites the Commission to submit a report to the Helsinki European Council with a view to safeguarding current sports structures and maintaining the social function of sport within the Community framework. The European Council underlines its concern at the extent and seriousness of doping in sports, which undermines the sporting ethic and endangers public health. It emphasises the need for mobilisation at European Union level and invites the member states to examine jointly with the Commission and international sports bodies possible measures to intensify the fight against this danger, in particular through better coordination of existing national measures. ${ }^{35}$

The Austrian Presidency broadened the scope of the discussion on sport to include an examination of ways sporting structures and the social dimension of sport could be safeguarded within the EU framework. This statement is significant in that the member states hinted that the EU should be adopting a more soft touch application of EU law to the sports sector. It is also possible that the member states were hinting at a possible future hardening of the Amsterdam Declaration. The onus was placed on the Commission to examine these issues via the presentation of a report on sport to the Helsinki European Council to be held in December 1999. In addition to the issue of sport and EU law, the Presidency Conclusions are also significant for the first real signs of a EU commitment to fighting doping in sport. 
The first European Union Conference on Sport (the Assises), May 1999 Attached to the Commission consultation document, The European Model of Sport, were a series of questionnaires designed to canvass opinion on the future structure of European sport, the future relationship between sport and television and the social dimension of sport, including doping issues. The Commission used the 100 replies to prepare the first EU conference on sport.

The conference was held in Greece in May 1999. The decision to hold it stemmed from a decision taken at the November 1998 European Sports Forum. The Amsterdam Declaration invited the Commission to establish a dialogue between sports organisations and the EU institutions. At the December 1998 Vienna European Council, the member states reaffirmed this desire by requesting the Commission to submit a report to the December 1999 Helsinki European Council with a view to safeguarding current sports structures and maintaining the social function of sport within the EU framework. The convening of the conference represents the Commission's response to these requests. Although the Commission's working paper and the consultation document also form part of this strategy, they also represent an 'in-house' attempt by the Commission to review the relationship between sport and the EU.

The conference participants were drawn from a wide range of backgrounds. ${ }^{36}$ The participants were divided into three main working parties each of which discussed one issue relating to sport. The three working parties were each presented with a discussion paper covering, 'The European Model of Sport, Including the Social Dimension of Sport', 'Relations Between Sport and Television' and 'The Fight Against Doping in Sport'.

The group discussing the 'European Model of Sport' drew a number of conclusions. First, they argued that sporting 'autonomy' should be safeguarded from economic and political influences and that a balance between these pressures needs establishing. Second, they argued that the federal structure of sport (described above) should be maintained and protected. As such, the participants wanted potentially restrictive rules deterring the formation of breakaway structures to be maintained. Third, the participants wished to see young sportspersons being afforded greater protection. In this connection, the participants invited bodies such as the EU to take sport into consideration in the fields of policies on social integration, anti-doping measures, anti-racism measures, environmental policy, public health policy, education policy and youth policy. Fourth, the participants re-affirmed the importance of equal opportunities in sport and the importance of sport for promoting the integration of disabled persons. Finally, the participants attempted to persuade the EU of the importance of supporting regional sport, particularly in Eastern Europe, the Mediterranean region and in developing countries.

The group examining the relationship between sport and television acknowledged the increased competition in the broadcasting sector but 
argued that the autonomy of sport should be maintained. In particular, they argued that sport should not be used by broadcasters simply to attract audiences, and broadcasters should not interfere or exercise control over the organisation and scheduling of sport. Many participants expressed opposition to attempts by media companies to acquire an interest in sports clubs. Furthermore, most of the participants expressed the view that the collective sale of sports rights by federations was the best system for ensuring effective redistribution and maintaining the solidarity of sport. Whilst the working group acknowledged the competition policy implications of long exclusive broadcasting contracts, they argued that the duration of such rights should be 'sufficient'. They concluded by suggesting that a single rule on this issue would not benefit sport given the wide variety of sporting disciplines. Finally, on the issue of public access to sports broadcasts, the working group acknowledged the public interest argument that was at the heart of Article 3a of the TWF Directive, but argued that a balance needed to be struck between the need to exploit the new commercial developments in the broadcasting sector and the need to guarantee public access to events on television.

The final working group examined the Commission discussion paper on the fight against doping in sport. The group argued that sports organisations, national governments and EU institutions should co-ordinate efforts in order to eliminate doping. In particular, the participants drew attention to the need for effective out-of-competition controls and the need for the harmonisation of lists of banned substances, procedures and penalties. It was also recommended that EU action in this field should be co-ordinated with that of the Council of Europe.

\section{The German Presidency (January-June 1999)}

The German Presidency convened an informal meeting of EU Sports Ministers to discuss the growing debate on the relationship between sport and the EU. Meeting in Paderborn (31 May-2 June 1999), the Ministers added to the Austrian Presidency's calls for more anti-doping measures in sport. In addition, they discussed the use of sport as a potential source of employment and the portrayal of sport for the disabled in the media. A discussion relating to sporting contacts with the Federal Republic of Yugoslavia and the provision of sport possibilities for refugees from Kosovo in the refugee camps in Albania and Macedonia also took place. The significant discussion related to the Amsterdam Declaration on Sport. In this connection the Ministers drew the following conclusions:

So as to safeguard the ethics and the social significance of sport, the particular concerns of sport should be supported especially in the following areas:

- the application of competition law and internal market rules;

- the EU measures relating to sport and television;

- Community actions in the field of sport; 
- the assistance programmes of the EU, in order to achieve greater transparency as regards the taking into account of sports;

- in light of the interest that the EU attaches to the campaign of the member states and of the sports organisations relating to the protection of minor athletes, the training of young persons, the social significance and the solidarity functions of sport.

The Sport Ministers invite the European Commission to set up a working group composed of representatives of the member states of the EU and of the Commission, which is to work out how the concerns of sport can be taken into account in the EU Treaty. In doing so, the Working Group will consult sport organisations. ${ }^{37}$

The conclusions relating to the Declaration have a strong socio-cultural character. The member states once again expressed the view that the relationship between sport and the EU Treaty should be further clarified without expressing a view as to how this should be achieved. Once again, the Ministers expected the Commission to propose such measures. However, the conclusions firmly indicate that the member states wish to see EU sports policy develop in a socio-cultural direction, be that in the way of a more sympathetic application of EU law to sport or through more formal Treaty measures. These conclusions have given considerable impetus to those socio-cultural actors who want the EU to adopt more formal Treaty measures in order to 'protect' sport from EU law.

\section{The Finnish Presidency (July-December 1999)}

In launching the priorities for the six-month term of office, the Finnish Presidency, in addition to carrying on discussions concerning anti-doping measures in sport, expressed the desire to, 'carry on the discussion on the status of sports in Community law, emphasising the social significance of sports and the need to take the special characteristics of sports into account in the application of legislation'. ${ }^{38}$

The Sports Directors of the EU member states met in Helsinki on the 18-20 October 1999 to discuss the sports-related Presidency priorities. Again, the conclusions of the meeting reflect a desire on the part of the member states to see the EU adopt a more holistic approach to sport. This naturally involves the EU promoting and safeguarding the socio-cultural dimension of sport in addition to recognising the economic dimension of sport. The Directors concluded, 'sport is an important resource that promotes people's well-being and health, the cultural dimension and social cohesion. Therefore, sport in its social significance should be seen as a broadbased sector' ${ }^{39}$ The Directors also discussed the establishment of the World Anti-Doping Agency (WADA), the use of sport for the social integration of young people, the use of sport as a source of employment, the use of sport as a civic activity promoting democracy in order to implement the Northern Dimension strategy of the EU, the use of sporting sanctions as a tool of 
foreign policy, the use of sport as a means of bringing the EU closer to EU citizens and mechanisms for improving the dialogue between the EU and the sports world. Following the meeting of the Directors, the Ministers for Sport met informally on 25 October in Vierumäki. At this meeting the Ministers agreed on the participation in the World Anti-Doping Agency for a two-year transitional period. Also at the meeting, the Commission submitted the Helsinki report on sport, a report requested by the member states during the Austrian Presidency.

\section{The Helsinki report on sport, December $1999^{40}$}

The conclusions of the May 1999 Conference on Sport were used by the Commission to respond to the member states request, made at the December 1998 Vienna European Council that the Commission should 'submit a report to the Helsinki European Council with a view to safeguarding current sports structures and maintaining the social function of sport within the Community framework'. Accordingly, in December 1999 the Commission submitted the Helsinki Report on Sport to the member states meeting in Finland. The bulk of the report is contained within three sections.

In the first section, the report claimed that the 'the development of sport in Europe risks weakening its educational and social function'. ${ }^{41}$ In particular, the report claimed that the 'European approach' to sport has recently been affected by several important developments. These developments include the growth in the popularity of sport, the increasing internationalisation of sport and the unprecedented development of the economic dimension of sport. The advantages of these developments for the European economy are considerable. The number of jobs created directly or indirectly by the sports industry has risen by 60 per cent in the past ten years to reach nearly two million. However, the above developments have also led to some 'tensions'. First, doping may be a bi-product of increased competition stemming from commercial developments. Second, commercialism may be squeezing traditional sporting principles out of sport. In particular, the social function of sport is being threatened. Third, commercial pressures may lead to the current single structure for sport being fragmented as some participants seek a more lucrative future in breakaway leagues. This may jeopardise financial solidarity between professional and amateur sport. Finally, the above developments are putting an increasingly physical and mental strain on young sports people, thus risking their subsequent switch to alternative employment.

The second part of the report argued that 'the Community, its member states and the sporting movement need to reaffirm and strengthen the educational and social function of sport'. ${ }^{42}$ In this connection the report makes two sets of recommendations. First, in relation to enhancing the educational role of sport, the report suggests that EU educational and training programmes could focus on (1) improving the position of sport and physical 
education at school through Community programmes; (2) promoting the subsequent switch to other employment and future integration on to the labour market of sportsmen and women; (3) promoting convergence between the training systems for sports workers in each member state. ${ }^{43}$ Second, concerning doping in sport, the report outlines the measures adopted by the Commission in relation to anti-doping policy. Doping issues have been referred to the European Group on Ethics and a World AntiDoping Agency has been established, following co-operation with the Olympic movement. Measures to improve legislative co-ordination with national anti-doping measures have also been explored.

The final section of the report, 'Clarifying the Legal Environment of Sport', examined the thorny issue of the relationship between sport and EU law. The report examined how the commercialisation of the sports sector has contributed to an increase in the number of conflicts involving EU law. These conflicts have ranged from disputes concerning the sale of television rights to issues of club ownership and geographical location. Quoting the conclusions of the first EU Conference on Sport organised by the Commission held in Olympia in May 1999, the paper argued that 'sport must be able to assimilate the new commercial framework in which it must develop, without at the same time losing its identity and autonomy, which underpin the functions it performs in the social, cultural, health and educational areas'. ${ }^{44}$

To enable the sports world to achieve this, the report identified a need for a 'new approach' for dealing with sports-related issues in the EU. As the report explains, 'this new approach involves preserving the traditional values of sport, while at the same time assimilating a changing economic and legal environment'. ${ }^{45}$ Action at three levels was recommended.

At the Community level, central to this 'legal environment', is the application of EU competition law. The report argues that 'the application of Treaty's competition rules to the sports sector must take account of the specific characteristics of sport, especially the interdependence between sporting activity and the economic activity that it generates, the principle of equal opportunities and the uncertainty of results' ${ }^{46}$ In this connection, the report provided examples of (1) practices which do not come under the competition rules, (2) practices that are, in principle, prohibited by the competition rules and (3) practices likely to be exempted from the competition rules. Nevertheless, the report did not confront the issue of how the special characteristics of sport could be more widely safeguarded in the absence of a Treaty base for sport. At the national level, the report proposed measures designed to protect the national single structure 'model' of sporting organisation. In particular, the report suggests that 'one way of safeguarding the national federal structures could be to provide for them to be recognised by law in each member state of the Union'. ${ }^{47}$ Finally, at the level of sporting organisations, the report suggested that sporting federations should more clearly define their 'missions and statutes'. This recommendation clearly 
places the emphasis on the federations to define the particular characteristics of sport and the measures they themselves have taken to protect and nurture such characteristics. Where sporting operations have a commercial dimension, the report argues that such operations must be 'founded on the principles of transparency and balanced access to the market, effective and proven redistribution and clarification of contracts, while prominence is given to the specific nature of sport'. Furthermore, regulatory measures should be 'objectively justified, non-discriminatory, necessary and proportional'48 If sporting rules conform to these 'tests', they should not conflict with Treaty provisions.

At the heart of the Helsinki report on sport lies the concept of 'partnership', a concept widely employed by EU officials. In this context partnership means the knitting together of the macro (EU institutions), meso (member states) and micro (sub-national groups and non-state actors) levels of activity to ensure a more structured and co-ordinated approach to sport. Simultaneously of course, partnership also draws a wide range of actors into the regional integration process and serves to legitimise EU involvement in policy areas. The report clearly links commercialisation with the 'juridification' of sport. As sporting operations practice increasingly on a commercial basis, so EU law seeps into the internal laws of sport. The clearest example of this, other than the Bosman ruling is the application of EU competition law to the sports sector. The danger is that the 'special characteristics' of sport become squeezed between these commercial and legal developments. The paper makes clear that action at EU level alone will be insufficient to protect current structures and the social function of sport. Hence a 'partnership' approach is recommended.

In their response to the Helsinki report, the Parliament's Committee on Culture, Youth, the Media and Sport broadly supported the Commission. ${ }^{49}$ In particular, the so-called Mennea report welcomed the Commission's focus on the social dimension of sport and their desire to clarify the legal environment within which sport operates in the EU. The report argues that the principles established in the Bosman ruling should be considered part of this legal environment and as such should not be undermined. The report therefore represents a continuation of Parliamentary thinking regarding the importance of extending the right of free movement to all EU citizens. Nevertheless, the report argues that the Amsterdam Declaration should be replaced with a Treaty Article for sport. Mennea supports the Pack recommendation of linking sport with cultural policy.

\section{The road to Nice and beyond}

Discussions on the fight against doping in sport and the social dimension of sport were continued by the Portuguese Presidency in the first half of 2000. The Sports Directors met in Lisbon in May in preparation for the informal 
meeting of Sports Ministers held on 10 May. At this meeting the Ministers recommended five developments in the field of EU sports policy. First, the establishment of an informal working group with the aim of proposing to the member states forms of participation with the WADA. Second, the Ministers argued that, 'the specific aspects of sport, namely its social dimension, should be taken into consideration in the implementation of Community policies'.$^{50}$ Third, the Ministers recommended 'the creation of a joint working group with representatives of the EU and the Commission, charged with studying the harmonisation of the specific aspects of sport within the Treaty of the Union'. ${ }^{51}$ In a footnote below this passage it was noted that the United Kingdom had refused to approve the establishment of a working group for the inclusion of a new paragraph in the Treaty. Fourth, the Ministers recommended the creation of training and exchange programmes for young sportspersons and, finally, the Ministers recommended the creation of a sports information network between member states that would act as a mechanism for the dissemination of information. Following the Santa Maria da Feira European Council meeting, the Presidency Conclusions relating to sport read, 'the European Council requests the Commission and the Council to take account of the specific characteristics of sport in Europe and its social function in managing common policies' ${ }^{52}$

The Portuguese discussions took place within the context of an on-going IGC process. The Amsterdam Treaty was designed to prepare the EU for the necessary deepening that was to take place prior to the successful widening of the organisation. In the event, the summit postponed many of the difficult decisions relating to the institutional reform of the EU. As a result, throughout much of 1999 and the first half of 2000, the EU embarked upon another IGC process in preparation for another revision to the Treaty (agreed December 2000 in Nice). This process has provided the socio-cultural coalition with another opportunity to push for more formal measures concerning the Treaty status of sport. In particular, the current debate on the Treaty status of sport has been heavily influenced by the debate within European football on how to mitigate the deleterious effects of Bosman. The Parliament once again emerged as an important forum through which such demands have been articulated.

Twenty national associations met at a joint FIFA/UEFA conference in Amsterdam in March 2000 to discuss the possibility of persuading the EU to adopt a protocol for sport within the newly revised Treaty. In April 2000, a FIFA/UEFA delegation floated the idea before the before the Parliament and met with the troika of EU Sports Ministers in Lisbon, Portugal. It was reported that FIFA/UEFA wanted sport to be granted a 'special status' within the Treaty. The meeting with the troika yielded two conclusions. First, a working committee was established by the Portuguese Presidency to discuss the proposal. Following the meeting, the Portuguese Minister for Sport 
remarked that there was a 'need to safeguard sport, notably soccer, from the perverseness that has emerged from the (Bosman) ruling'. ${ }^{53}$ Second, the Ministers committed themselves to examining the merits of a protocol for sport being adopted in the newly revised Treaty and that this issue would be discussed at the meeting of all 15 member state Sports Ministers in May $2000 .{ }^{54} \mathrm{~A}$ sporting protocol, if adopted could allow sport a derogation from certain aspects of EU law without the need to re-write the provisions on free movement and competition law. At this meeting, UEFA President claimed that the protocol idea had met with 'understanding' from MEP's. ${ }^{55}$

The negotiation of the Nice Treaty, gave the French Presidency (June-December 2000) the opportunity to present their sports-related ideas to a wider forum whilst offering the European Council an opportunity to formally respond to the Helsinki report on Sport. In particular, the French Presidency expressed the desire that the conclusions of the working group should form the basis of discussions at the 9th European Sports Forum held in Lille on 26 and 27 October 2000 and that the conclusions of this meeting would lead to the adoption of 'significant' steps by the Nice European Council on 7 and 8 December 2000.

In the event, at Nice the protocol approach advocated by UEFA and FIFA was rejected by the member states in favour of a further Declaration on Sport presented as a Presidency Conclusion. The Declaration, reproduced in full below, is significant in that the member states offered some guidance as to the immediate resolution of (as then) pending disputes (notably the transfer issue) whilst also laying down some signposts for the longer-term future of EU involvement in sport. The Declaration read:

\section{DECLARATION ON THE SPECIFIC CHARACTERISTICS OF SPORT AND ITS SOCIAL FUNCTION IN EUROPE, OF WHICH ACCOUNT SHOULD BE TAKEN IN IMPLEMENTING COMMON POLICIES}

Presidency Conclusions, Nice European Council Meeting, 7, 8, 9 December 2000

1 The European Council has noted the report on sport submitted to it by the European Commission in Helsinki in December 1999 with a view to safeguarding current sports structures and maintaining the social function of sport within the European Union. Sporting organisations and the member states have a primary responsibility in the conduct of sporting affairs. Even though not having any direct powers in this area, the Community must, in its action under the various Treaty provisions, take account of the social, educational and cultural functions inherent in sport and making it special, in order that the code of ethics and the solidarity essential to the preservation of its social role may be respected and nurtured.

2 The European Council hopes in particular that the cohesion and ties of solidarity binding the practice of sports at every level, fair competition and both the moral and material interests and the physical integrity of those involved in the practice of sport, especially minors, may be preserved. 


\section{Amateur sport and sport for all}

3 Sport is a human activity resting on fundamental social, educational and cultural values. It is a factor making for integration, involvement in social life, tolerance, acceptance of differences and playing by the rules.

4 Sporting activity should be accessible to every man and woman, with due regard for individual aspirations and abilities, throughout the whole gamut of organised or individual competitive or recreational sports.

5 For the physically or mentally disabled, the practice of physical and sporting activities provides a particularly favourable opening for the development of individual talent, rehabilitation, social integration and solidarity and, as such, should be encouraged. In this connection, the European Council welcomes the valuable and exemplary contribution made by the Paralympic Games in Sydney.

6 The member states encourage voluntary services in sport, by means of measures providing appropriate protection for and acknowledging the economic and social role of volunteers, with the support, where necessary, of the Community in the framework of its powers in this area.

\section{Role of sports federations}

7 The European Council stresses its support for the independence of sports organisations and their right to organise themselves through appropriate associative structures. It recognises that, with due regard for national and Community legislation and on the basis of a democratic and transparent method of operation, it is the task of sporting organisations to organise and promote their particular sports, particularly as regards the specifically sporting rules applicable and the make-up of national teams, in the way which they think best reflects their objectives.

8 It notes that sports federations have a central role in ensuring the essential solidarity between the various levels of sporting practice, from recreational to top-level sport, which co-exist there; they provide the possibility of access to sports for the public at large, human and financial support for amateur sports, promotion of equal access to every level of sporting activity for men and women alike, youth training, health protection and measures to combat doping, acts of violence and racist or xenophobic occurrences.

9 These social functions entail special responsibilities for federations and provide the basis for the recognition of their competence in organising competitions.

10 While taking account of developments in the world of sport, federations must continue to be the key feature of a form of organisation providing a guarantee of sporting cohesion and participatory democracy.

\section{Preservation of sports training policies}

11 Training policies for young sportsmen and -women are the life blood of sport, national teams and top-level involvement in sport and must be encouraged. Sports federations, where appropriate in tandem with the public authorities, are justified in taking the action needed to preserve the training capacity of clubs affiliated to them and to ensure the quality of 
such training, with due regard for national and Community legislation and practices.

\section{Protection of young sportsmen and -women}

12 The European Council underlines the benefits of sport for young people and urges the need for special heed to be paid, in particular by sporting organisations, to the education and vocational training of top young sportsmen and -women, in order that their vocational integration is not jeopardised because of their sporting careers, to their psychological balance and family ties and to their health, in particular the prevention of doping. It appreciates the contribution of associations and organisations which minister to these requirements in their training work and thus make a valuable contribution socially.

13 The European Council expresses concern about commercial transactions targeting minors in sport, including those from third countries, inasmuch as they do not comply with existing labour legislation or endanger the health and welfare of young sportsmen and -women. It calls on sporting organisations and the member states to investigate and monitor such practices and, where necessary, to consider appropriate measures.

\section{Economic context of sport and solidarity}

14 In the view of the European Council, single ownership or financial control of more than one sports club entering the same competition in the same sport may jeopardise fair competition. Where necessary, sports federations are encouraged to introduce arrangements for overseeing the management of clubs.

15 The sale of television broadcasting rights is one of the greatest sources of income today for certain sports. The European Council thinks that moves to encourage the mutualisation of part of the revenue from such sales, at the appropriate levels, are beneficial to the principle of solidarity between all levels and areas of sport.

\section{Transfers}

16 The European Council is keenly supportive of dialogue on the transfer system between the sports movement, in particular the football authorities, organisations representing professional sportsmen and -women, the Community and the member states, with due regard for the specific requirements of sport, subject to compliance with Community law.

17 The Community institutions and the member states are requested to continue examining their policies, in compliance with the Treaty and in accordance with their respective powers, in the light of these general principles. ${ }^{56}$

Through the Declaration, the member states continued to insist on the special place of sport with the EU's legal framework without committing themselves to formal legal means to secure this. This point was picked up on by the Parliament's Draft Opinion of the Committee on Culture, Youth, Education, the Media and Sport for the Committee on Constitutional Affairs on the Nice Treaty. ${ }^{57}$ In the draft opinion the Parliament remarked: 
the Committee has always emphasised the important health, educational and social aspects to sport; and has consistently called for the introduction of a legal basis making possible Community action in the field of sport . . The Amsterdam Treaty included a Declaration on Sport and the Treaty of Nice includes an Annex (Annex IV) on sport: neither of these, however, constitutes a legal basis for Community action.' In this connection the Committee 'regrets that its long-standing appeal for the inclusion in the Treaty of a legal basis for Community action in the field of sport has once again been rejected; and calls for the creation of such a legal base in any future revision of the Treaty'. ${ }^{58}$

Presidency follow-up discussions on sport took place throughout 2001 and 2002. In a series of meetings throughout the first half of 2001, the Swedish Presidency conducted a review of attitudes towards the Nice Declaration and carried on discussions on the fight against doping and the operation of WADA. These issues were continued by the Belgian Presidency in the second half of 2001. In October 2001, the Commission presented a proposal for the establishment of the European Year of Education through sport (2004). ${ }^{59}$ This issue along with the question of the implementation of the Declaration and doping are now the key sports-related issues in the EU. However, also in 2004, the EU is committed to a revision of the Treaty. This is likely to be the fourth major sporting issue to appear on the Presidency's agenda.

The 10th annual European Sports Forum meeting in Brussels in October 2001 provided a forum for a review of EU sports policy at a crucial time for the sports world. The Forum established four working groups: Implementation of the Nice Declaration, Fight Against Doping, Social Economy, Sport for Disabled People. The discussion paper prepared for the Nice Declaration working group identified the following as key issues: ${ }^{60}$

- The place of sports federations in the organisation of sport today. Should they have an exclusive role? Should other forms of organisation of sport be examined? Should other structures independent of the federations have a role to play in the organisation of sport and competitions?

- Internal organisation of the sports organisations. How do they or should they take account of the new economic environment? Seek transparency and more democracy? Ensure that all categories of members are represented in the ruling bodies?

- Does not the emergence and success of international and European championships jeopardise the national base of sports' organisation? Is the national framework sometimes not too narrow for the organisation of certain championships? What should be done in the light of these developments?

- How should television rights be managed? How can the rights of each club and the principle of solidarity at the heart of federal organisations be reconciled? What are the national and Community approaches to this? 
- How should the professionalisation of sport and its ever-increasing economic impact be analysed? Is this a favourable, unavoidable trend? Should it be brought under control? How? Where does voluntary activity fit into this context?

- Is there a Community-level social dialogue between the various partners involved in sport? Should it be supported? What should it be seeking to achieve?

- Protection of young people. What dangers lurk for young people? How can they be protected? Who should be responsible for implementing this protection? The federations? The public authorities? How?

- What place should sport have in Community policies? A specific place? Better consideration within other policies?

In the Nice working group's conclusions, the participants welcomed the political involvement of the members states through the release of the Nice Declaration. ${ }^{61}$ Describing the Declaration as a 'breakthrough', the EU was urged to follow up the Declaration through the promotion of the ethical and social values of sport. The group also welcomed the outcome of competition law cases following the Declaration. The group noted that the sports-related cases had 'been dealt with in a way which respects Community law and the uniqueness of sport, and in line with the spirit advocated by the Nice Declaration'. ${ }^{62}$ However, the group expressed the view that whilst the autonomy of sport should be respected, sport should be more closely integrated into a range of EU policies.

\section{Comment}

In attempting to challenge the dominance of the market-based approach of the ECJ and Competition Policy Directorate in order to redefine sport as a more social pursuit, the socio-cultural actors have encountered a number of difficulties. First, the EU has enshrined its market-based definition of sport in law. ECJ jurisprudence clearly links EU law to the practice of sport. Second, the EU lacks a Treaty base for sport. This limits the ability of the socio-cultural coalition to address sporting issues in non-Single Market policy venues. Third, the socio-cultural coalition is a coalition of convenience. It lacks unanimous agreement on policy strategy. Despite having access to numerous institutional venues, this lack of cohesion forecloses many legislative venues. As a result of these constraints, the activity of the socio-cultural coalition has been largely confined to the use of soft law. Although soft law is not legally binding it does still carry weight in the EU.

European Parliament initiatives The European Parliament's sporting initiatives are consistent with the people's Europe project. However, the Parliament has not attempted to overturn the Bosman ruling because the 
establishment of a people's Europe requires discriminatory practices in sport to be abolished. As such, whilst both the Larive and Pack reports seek to establish a more socio-cultural definition of sport, they also support EU action to prohibit restrictive practises in sport. Due to the lack of a Treaty base for sport, the Parliament has attempted to assert its agenda through essentially ad hoc ventures into sports policy. In particular, the Parliament has used its budgetary, legislative and scrutiny powers to press for more EU involvement in sport. The Parliament's exploitation of its budgetary powers to keep the sports budgetary line afloat and its exploitation of legislative powers to revise the Television Without Frontiers Directive represent the most effective use of its formal powers.

Member state initiatives Member state involvement in sports policy intensified post-Bosman following concerns raised by some governments on the direction of sports policy. The member states responded by establishing political guidelines for the future direction of sports policy. The most significant of these guidelines was the Amsterdam Treaty's Declaration on Sport. Previously at Milan in 1985 and at Maastricht in 1992, the member states had recognised the importance of social and cultural measures to the foundations of European integration. The Maastricht Treaty contained provisions on social, cultural and tourism policy. The inclusion of sport within the Treaty at Amsterdam was therefore a natural progression, particularly given the problematic ratification of the Maastricht Treaty and the subsequent desire on the part of the member states to bring Europe closer to the citizens. The Amsterdam Declaration has proved important, not only in guiding the application of EU law to sport, but also in progressively hardening sports policy. The contribution of soft law to policy development is an area frequently overlooked by researchers, yet one almost always in evidence in the history of the establishment of a new policy sector. Following Amsterdam, sports policy developed from a narrow examination of the relationship between sport and employment (2nd half 1997) to the adoption and implementation of the Nice Declaration on Sport (2nd half of 2002). The relative freedom of the Council Presidency to push individual agendas is significant in this respect (Kirchner 1992). Furthermore, the troika system allows for the preceding Presidency's agenda to be continued by the successor whilst also being coupled with the agenda of the successor Presidency.

Commission initiatives The Commission's response to member state promptings has also come largely in the form of policy papers. Using its right of policy initiative, the Education and Culture Directorate has pieced together a series of measures, which, when taken together, represent a 'new approach' to sports policy. The two 1998 policy papers, 'The development and prospects for Community action in the field of sport', and 'The European model of sport' were used to prepare for the first EU conference 
on sport, held in Greece in May 1999. The conclusions of this exercise were used by the Commission to respond to the member states request, made at the December 1998 Vienna European Council that the Commission should write the Helsinki report on sport. This report states the current state of play.

Despite the predominance of soft law as a tactic with which to influence the definition of sport in the EU, the activities of the socio-cultural coalition have had some practical effects. Above all, the sports policy subsystem has been politicised. Previously dominated by legal norms, the subsystem has become penetrated by essentially political arguments concerning the social significance of sport. This politicisation has been aided by the high political salience of sport in Europe. Sport is an issue carrying very high public interest. Politicisation is an essential pre-requisite for policy change.

Policy change is evident within the sports policy subsystem. The key consequence of subsystem politicisation has been a change in the regulatory conditions within which sport operates. In other words the regulation of sport in the EU has been politicised. This politicisation of sports regulation has resulted in a drift from a Single Market model of sports regulation towards a socio-cultural model. Single Market regulation refers to regulation designed to protect and enhance the four fundamental freedoms. Sociocultural regulation refers to a more sympathetic/soft touch application of this logic in which the specific and possibly unique characteristics of the sector are taken into consideration. The ECJ rulings in Deliège and Lehtonen and the Competition Directorate's post-Amsterdam approach for dealing with sport illustrates the extent to which political arguments have influenced the application of the EU law to sport. As such, these rulings/decisions are significant in that they mark the birth of an area of EU law called 'EU sports law'. It is to this issue that the final chapter now turns.

\section{Notes}

1 COM (84) 446 Final, A People's Europe, reports from the ad hoc Committee.

2 Ibid., para. 5.9.

3 A5-0133/2002b, 'Report on the division of competences between the European Union and the Member States' (2001/2024(INI)), Committee on Constitutional Affairs, 24/04/02. Rapporteur: Alain Lamassoure, pp. 18-19.

4 A-0415/88, 'Report for the Committee on Legal Affairs and Citizen's Rights, on the freedom of movement of professional footballers in the Community', 03/89. Rapporteur: J. Van Raay.

5 A3-0326/94/ Part A (27/4/94) Part B (29/4/94), 'Report on the European Community and Sport', Rapporteur: Mrs J. Larive.

6 A1-53/84, 'Sport and the Community' (Rapporteur: Mr Bord MEP); A2-32/87, 'Women in Sport' (Rapporteur: Mrs d'Ancona MEP); A2-70/85 and A2-215/87, 'Vandalism and Violence in Sport' (Rapporteur: Mrs Larive MEP); A2-282/88, 'Sport in the European Community and a People's Europe' (Rapporteur: Mrs Larive MEP). 
7 B3-1909/90, 'Motion for a Resolution of 8/11/90 on the Protection of Popular Sporting Traditions in Europe', Rapporteur: Mrs Ewing.

8 B3-0862/91, 'Motion for a Resolution of 10/6/91 on the Need to Reappraise the EC's Sports Policy', Rapporteur: Mrs Banotti.

9 B3-1512/91, 'Motion for a Resolution of 15/10/91 on Professional Boxing', Rapporteur: Mr Díaz.

10 B3-1725/91, 'Motion for a Resolution of 12/11/91 on a Common Logo for Athletes from the 12 Member States Taking Part in the Next Olympic Games', Rapporteur: Mrs Muscardini.

11 B3-0456/92, 'Motion for a Resolution of 15/4/92 on Legislation to Outlaw Symbols Which Incite Violence in Sport', Rapporteur: Mr Abeilhe et al.

12 B3-0714/92, 'Motion for a Resolution of 1/6/92 on the Safety of Sports Installations', Rapporteur: Mrs Muscardini.

13 A4-0197/97. 'Report on the Role of the European Union in the Field of Sport', 28/5/97. Rapporteur: Mrs D. Pack

14 Ibid., para. A.

15 Ibid., para. B.

16 Ibid., para. I.

17 Ibid., section B, Explanatory statement.

18 See Case C-155/73, Italy v. Sacchi [1974] ECR 409 and Case C-52/79, Procureur du Roi v. Debauve [1980] ECR 833.

19 See Sacchi and Case C-260/89, ERT v. DEP [1991] ECR I-2925. Also Case C353/89, Commission v. Netherlands [1991] ECR I-4069. Case C-148/91, Vereniging Veronica v. Commissariaat voor de Media [1993] ECR I-487. Case C-23/93, TV10 SA v. Commissariaat voor de Media [1994] ECR I-4795.

20 Com (84) 300, 'On the Establishment of the Common Market Broadcasting, especially by Satellite and Cable’, 1984.

21 Article 251 (ex 189b).

22 European Parliament reference: A4-346/96.

23 Article 3a Directive 97/36/EC.

24 Declaration 29, Treaty of Amsterdam amending the Treaty on European Union, the Treaties establishing the European Communities and certain related Acts, 1997.

25 Chamberlain, P. (1998), UK Presidency of the European Union. Troika Meeting of EU Sports Ministers, Twickenham Stadium, 2 April 1998. Sport and Recreation Division, 8/4/98.

26 British Presidency Conclusions (15-16/6/98), Cardiff European Council.

27 'Development and Prospects for Community Activity in the Field of Sport', Commission Staff Working Paper, Directorate General X, 29/09/98.

28 Ibid., para. 3.1.

29 Ibid., para. 3.1.

30 Ibid., para. 4.2.

31 'The European model of sport'. Consultation Document of DG X. 1998.

32 OJ C 374, 23/12/99, Opinion of the Committee of the Regions on 'The European Model of Sport'.

33 Ibid., para. 4.4.

34 Ibid., para. 4.2.

35 Austrian Presidency Conclusions (11-12/12/98), The Vienna European Council Presidency Conclusions. 
36 For more on these participants, see Chapter 3 on the composition of the sports policy subsystem.

37 German Presidency Conclusions (31/5-2/6 99), Conclusions of the German European Council Presidency on the Occasion of the Informal Meeting of the Sport Ministers of the European Union - 'the Paderborn Conclusion'.

38 Finnish Ministry of Education (1999), Priorities: Ministry of Education, Finnish EU Presidency Website.

39 Finnish Presidency Conclusions (18-20/10/99), Sports Directors Meeting. Conclusions of the Presidency.

40 Com (1999) 644, 'Report from the Commission to the European Council with a view to safeguarding sports structures and maintaining the social significance of sport within the Community framework: the Helsinki report on sport', 1/12/99.

41 Ibid., para. 2.

42 Ibid., para. 3.

43 Ibid., para. 3.1.

44 Ibid., para. 4.

45 Ibid., para. 4.2 .

46 Ibid., para. 4.2.1.

47 Ibid., para. 4.2.2.

48 Ibid., para. 4.2.3.

49 A5-0208/2000, 'Report on the Commission Report to the European Council with a View to Safeguarding Current Sports Structures and Maintaining the Social Function of Sport within the Community Framework - The Helsinki Report on Sport', The Mennea report, 18/07/00.

50 Conclusions of the Informal Council of Ministers of Sport of the European Union, Lisbon, 10/5/00.

51 Ibid.

52 Portuguese Presidency Conclusions (19-20/6/00), Presidency Conclusions, Santa Maria da Feira European Council.

53 BBC Online, 17/3/00.

54 'FIFA and UEFA to Intensify Dialogue with EU', UEFA News Release, 1/3/00. 'UEFA to Intensify Dialogue with European Parliament', UEFA News Release, 13/4/00. 'UEFA Chief Executive Hopeful EU Will Introduce New Measures', UEFA News Release, 13/4/00.

55 BBC Online, 12/4/00.

56 'Declaration on the Specific Characteristics of Sport and its Social Function in Europe, of Which Account Should be Taken in Implementing Common Policies', Presidency Conclusions, Nice European Council Meeting, 7, 8, 9 December 2000.

57 PE 286.761, 'Draft Opinion of the Committee on Culture, Youth, Education, the Media and Sport for the Committee on Constitutional Affairs on the Treaty of Nice and the Future of the European Union', 23/03/01, Draftsman: Barbara O'Toole.

58 PE 286.761, pp. 4-6.

59 Com (2001) 584 final, 'Proposal for a Decision of the European Parliament and of the Council Establishing the European Year of Education through Sport 2004'. 
60 10th European Sports Forum. Framework document for working group discussions on the implementation of the Nice Declaration. Non-paper. 17/18 October 2001.

61 10th European Sports Forum. Conclusions of the working group on the follow up to the Nice Declaration. 17-18/10/01.

62 Ibid., para. 3. 